nearby northern States. Saskatchewan populations levels are at this point unknown.

a The Catley property is located along the south slope, directly across the valley from the midpoint of Highway 99. Specific directions and instructions for seeking permission to enter this restricted area may be obtained by contacting Robert Kreba (787-2807) or Bob Luterbach (790-8364).

\title{
SOME BIRD OBSERVATIONS IN MANITOBA IN 1999
}

BILL KOONZ, Wildlife Branch, Manitoba Conservation, Box 24, 200 Saulteaux Crescent, Winnipeg, MB R3J 3W3

\section{Long Point - June 1}

On June first, Robert Jones (retired bird biologist) and I visited the Gull Bay Sand Spit on the south side of Long Point, Manitoba $\left(52^{\circ} 58^{\prime} \mathrm{N}, 98^{\circ} 54^{\prime} \mathrm{W}\right)$. Long Point sticks out into the west side of Lake Winnipeg near its north end. The sand spit has been growing southwestward for over 30 years. It had attained a length of over 6 kilometres and was nearly a kilometre wide in places before being cut off at the base by lake currents in the spring of 1998 . This spit had been home for a huge Caspian Tern colony in the 1970s when it also had been an island'. Its broad beaches have provided nesting sites for one of the two largest known Piping Plover breeding areas in Manitoba. It was established as the Walter Cook Special Conservation Area by Manitoba Order in Council in 1991. Walter Cook (now deceased), a lifelong Grand Rapids trapper, hunter, fisherman and naturalist, was the first Manitoban to recognize the area as important for nesting Piping Plovers. By the spring of 1999 , the spit had already become a breeding colony for over 2,000 Ringbilled Gull and 2,000 Common Tern pairs. Over 60 Herring Gull nests also were counted there in 1999. Most of the shorelines are eroding, reducing the habitat available for Piping Plovers, but 14 were recorded there on 1 June. Of special interest was the observation of an adult male Lark Bunting recorded on the spit. It was enough of a treat to see Common Grackles, Red-winged Blackbirds, Brown-headed Cowbirds and Brewer's Blackbirds in the same shrub, but having the Lark Bunting there as well made it even more exciting.

\section{Lake Winnipegosis - June 4-11}

On June 4 to 11 , I took part in a boat cruise to count the numbers of nesting colonial waterbirds on Lake Winnipegosis. Participants also included John Weier (author and bird watcher), Don Campbell (retired provincial government photographer) and Doug and Harvey Brown (the captain and his son). Some of the highlights included five Great Blue Heron nests on the ground, a Bald Eagle 
nest in the same elm tree as four Doublecrested Cormorant nests, and observations of Canada Goose flocks (1582 individuals) totalling over 360 birds. Also of interest were large numbers of shorebirds including over 150 Sanderlings, 75 Ruddy Turnstones, 60 Semi-palmated Sandpipers and a dozen White-rumped Sandpipers. The most abundant nesting waterfowl was the Gadwall, however both Red-breasted and Common mergansers were abundant on the lake's many boulder-strewn islands. The biggest surprise was what appeared to be a second-year Common Loon seen by John Weier and Bill Koonz on June 7 near the south end of Sawbill Island, east of Birch Island (Latitude $52^{\circ} 15^{\prime} \mathrm{N}$; Longitude $99^{\circ} 50^{\prime} \mathrm{W}$ ). We observed the bird for several minutes, attempting to declare it something else (Red-necked Grebe? Arctic Loon?), but decided that it was indeed a juvenile Common Loon, or at least a Common Loon in juvenile plumage.

The colonial waterbird colony information provided big numbers and food for thought (Table 1). On islands where large Caspian Tern, Common Tern and Ring-billed Gull colonies overlapped, there was chaos when disturbance took place. Overlap areas were typically destroyed by our presence, so nest counts on those islands were estimates only. On islands occupied by a number of species including pelicans, cormorants, gulls and terns, the pelicans and cormorants often buffered the gull and tern nesting cells. Tern and gull colonies were separated by the earlynesting pelicans and cormorants. This separation appeared to greatly lessen the stress shown on islands where the gull and tern colonies overlapped.

It appeared that the large nesting colony sites were similar to atolls in the sense that the birds' excrement produces an aquatic bloom in the surrounding waters. These blooms provide food for the terns. Cormorants appear to be food finders, habitat makers and buffers for other species. They pioneer new colonies on treed islands. The vegetation dies over time, resulting in habitat for associated species.

\section{Table 1. Total numbers of nests counted during a survey of colonial}

waterbirds on Lake Winnipegosis, Manitoba, June 4-11, 1999.

Species

Double-crested Cormorant

American White Pelican

Ring-billed Gull

Caspian Tern

Common Tern

Herring Gull

California Gull

Great Blue Heron

Black-crowned Night-heron
Number of nests counted and estimated ${ }^{a}$

36,497 nests on 35 islands

7,769 nests on 9 islands

11,594 nests on 26 islands

5,868 nests on 8 islands

2,618 nests on 19 islands

783 nests on 39 islands

618 nests on 3 islands

188 nests on 7 islands

22 nests on 3 islands

a See text for explanation of counts 
Nests were counted by observation using hand counters on most colonies; it was difficult to quickly differentiate Ring-billed Gull nests from Caspian Tern and California Gull nests where the colonies overlapped. Estimates of Common Tern nests are low because this species was just initiating nesting on many colonies. The number of nests on several American While Pelican and Caspian Tern colonies was estimated on the basis of the area covered by the colony because of the risks posed by human disturbance and heat to nests, and recently hatched young, had the colony been visited.

\section{West Shoal Lake - July 14}

West Shoal Lake in Manitoba's Interlake region was the field site of Sue Haig's doctoral research on the Piping Plover. ${ }^{2,3}$ A recent increase in the area's water level has resulted in her entire study area being under water. The water of the lake is well over a metre above what it was in the mid-1980's. The result has been an elimination of Piping Plover habitat on the lake. The peninsula that Sue Haig had worked on now is three islands, the most easterly of which contained a Ring-billed Gull colony of over 1000 pairs in 1999. When I visited the site on July 14 , it also harbored over 50 loafing cormorants and 50 pelicans. Of particular interest was a large Western Grebe colony on the lake and at least four adult grebes with young on their backs. American Avocets, Willets, Marbled Godwits and Upland Sandpipers are some of the species identified as successfully nesting around the lake in 1999.

\section{Churchill - July 30 - Aug. 9}

I visited the Hudson Bay coast in the Churchill area, banding family groups of Canada Geese from July 30 to August 9. During that period, I visited areas from the North Knife River north of Churchill to York Factory south of Churchill. Goose nesting, of both Canada and Lesser Snow, was early and excellent in 1999 due, in part, to the early spring and a warm, dry summer. What struck

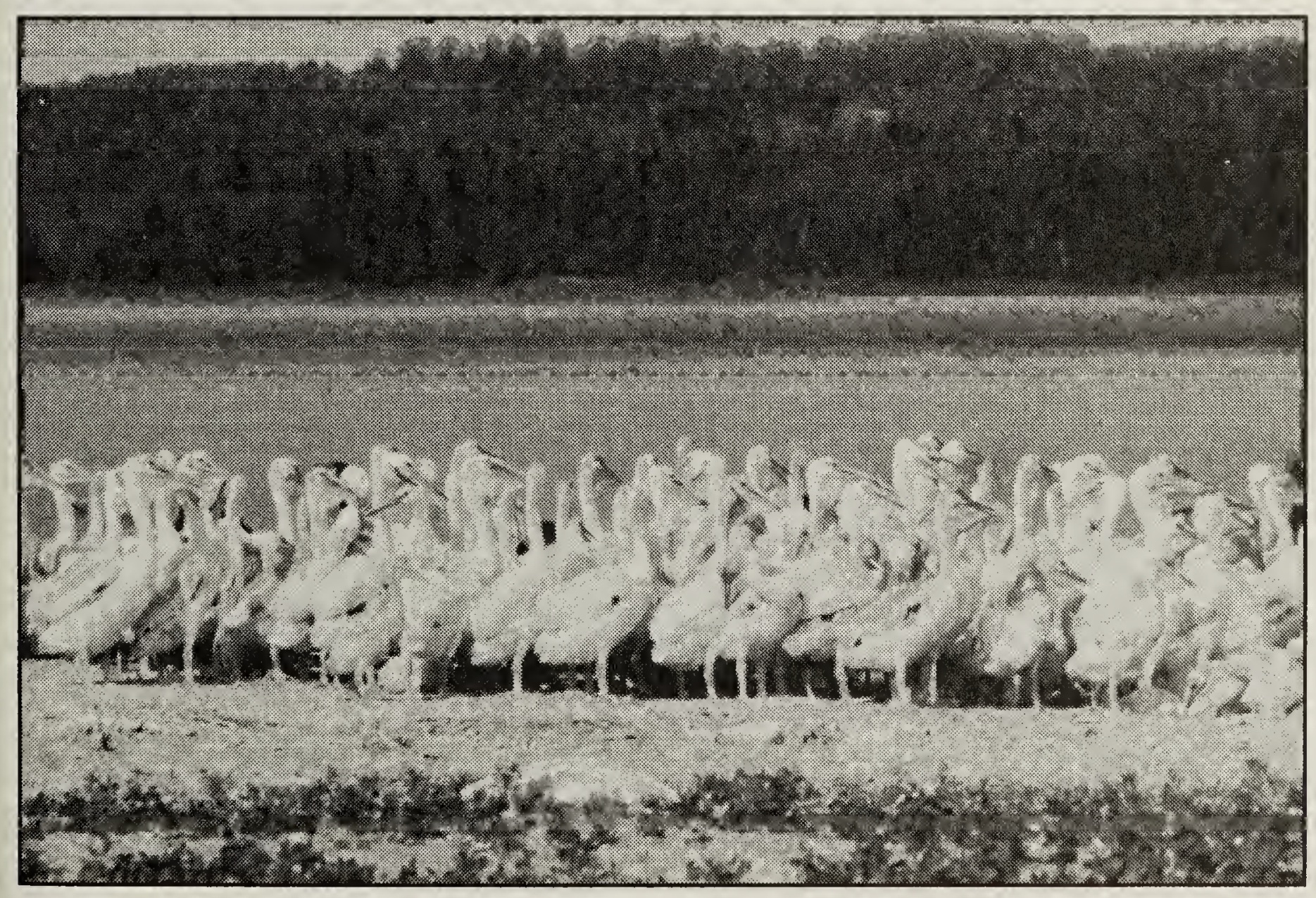


me were the large numbers of Sandhill Cranes that were seen all along the coastal areas visited. Also of interest were more than 130 Bald Eagles seen there. The eagles appeared to be feeding on geese as one captured goose had its scalp feathers removed and two others had their necks gashed. There also were large numbers of Northern Harriers as well as several Short-eared Owls, but these species were not associated with the goose concentrations. A Northern Shrike was spotted at York Factory on August $4^{\text {th }}$. On August $4^{\text {th }}$ and $5^{\text {th }}$, we noticed Bank Swallows living in birdhouses at the York Factory residence. There were an additional dozen occupied nests side by side along the roof of a shed. There also were Bank Swallows nesting along the banks of the Hayes River just downstream from York Factory. Shorebirds abounded throughout the period of visitation. Flocks of thousands were common along the exposed beaches, feeding in tidal areas and inland when the tide was high. There were more than 1500 Whimbrels on the rocks at Cape Mary for at least three consecutive days (Aug 1-4).

\section{Bruxelles - November 10}

On November 10, while walking through open stands of mature oaks southeast of Bruxelles (south of Spruce Woods), I heard a parrot-like song. Upon closer investigation, I determined that the source was a Northern Shrike. I have seen a number of Northern Shrikes in the fall and winter, but I had never heard one giving his full song, which was repeated a dozen or so times over the half hour that I was listening. November 1999 was extremely warm and sunny, and this may have put the bird in a festive mood.
1. Vermeer, K. 1970. Large colonies of Caspian Terns on Lake Winnipeg and Winnipegosis, 1970. Blue Jay 28: 117118.

2. Haig, S.M. 1986. Status of the Piping Plover in Manitoba: management recommendations for recovery. In: Proceedings of Prairie Endangered Species Symposium. Canadian Wildlife Service, Edmonton, AB.

3. Haig, S.M. 1987. Population Biology and Life History Strategies of the Piping Plover. Ph.D. dissertation, University of North Dakota.

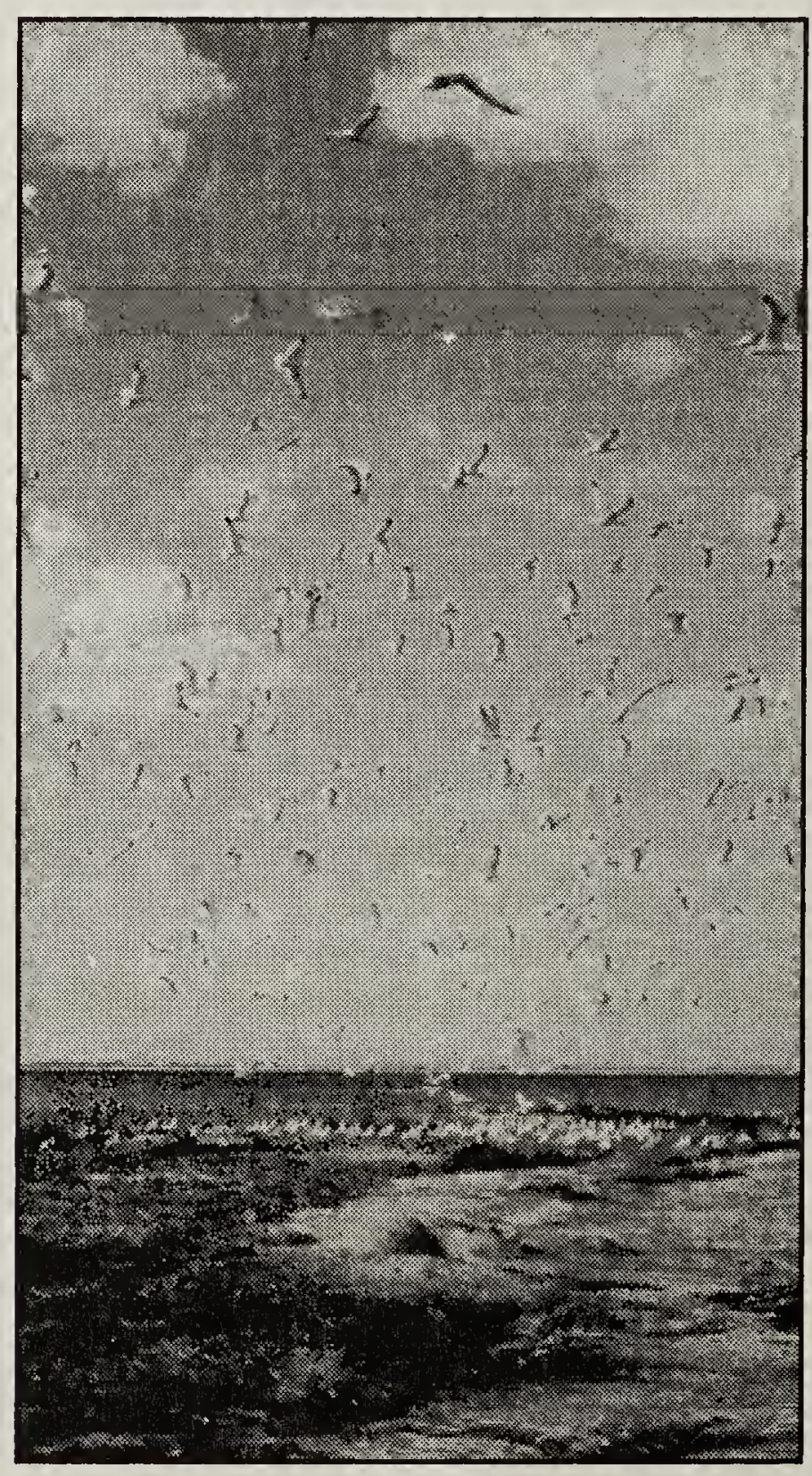

Ring-billed Gull colony, Last Mountain Lake, SK Gary Anweiler 